tiful plant resembling in many respects Conf. gracilis, Griff., but much more slender, and indeed nearly as soft and fine as an Ectocarpus. This is dedicated to Mrs. Kane, lady of Professor Kane, who was present at its discovery, and who some years ago published an Irish Flora.

Much praise is due to $\mathrm{Mr} . \mathrm{M}^{\mathrm{c}}$ Calla for the zeal and ability with which he has explored the west coast, and the creditable manner in which he has edited the present work. His future volumes will, we doubt not, contain an equal number of interesting plants. He proposes, we understand, shortly to visit our northern shores, so famous for the magnificent growth of Floridea, and his second volume will be ornamented with the finest of these. We heartily wish him the success which so praiseworthy an undertaking deserves.

\title{
Prodromus Systematis Naturalis Regni Vegetabilis, editore et pro parte auctore Alph. DeCandolle. Vol. ix. Paris, 1845.
}

We have just received the new volume of this valuable work, which is far too well known to require any praise from us. The orders Loganacea, Gentianea, Bignoniacea, Cyrtandracea, Polemoniacea, Convolvulacea, part of Boraginea, and a few lesser orders are included in this volume. A considerable portion is from the pen of the elder DeCandolle, and is illustrated by notes from his son's hand; the remainder consists of the labours of well-known botanists, each upon that order with which he is best acquainted. The additional observations appended to the specific character of each species seem to be rather fuller than in former volumes. It is stated that vol. $x$. is in the press.

\section{Works just Published.}

Descriptions of the Grasses of Britain, illustrated by 210 Figures drawn and engraved by the author, Richard Parnell, M.D., F.R.S.E.

The work contains a figure and description of every grass found in Britain, with their agricultural uses, \&c.

Cornish Fauna, being a Compendium of the Natural History of the County. Part 3: Zoophytes and Calcareous Corallines. By R.Q. Couch, M.R.C.S.L.

\section{PROCEEDINGS OF LEARNED SOCIETIES.}

\section{LINNAEAN SOCIETY.}

June 18,1844.-The Lord Bishop of Norwich, President, in the Chair.

Read the conclusion of Mr. Griffith's memoir "On the RootParasites referred by authors to Rhizanthea, and their Allies."

This extensive memoir, or series of memoirs, commences with "An Attempt to analyse Rhizantheae," as established by Prof. Endlicher and by Prof. Lindley, from which the author deduces the inference, " that in the construction of the group called Rhizanthece, a 


\section{$2 \mathrm{BHL}$ Biodiversity Heritage Library}

1845. "Prodromus systematis naturalis regni vegetabilis, editore et pro parte auctore Alph. DeCandolle. Vol. ix. Paris, 1845." The Annals and magazine of natural history; zoology, botany, and geology 15, 190-190.

https://doi.org/10.1080/037454809495292.

View This Item Online: $\underline{\text { https://www.biodiversitylibrary.org/item/19398 }}$

DOI: https://doi.org/10.1080/037454809495292

Permalink: https://www.biodiversitylibrary.org/partpdf/23861

\section{Holding Institution}

Natural History Museum Library, London

\section{Sponsored by}

Natural History Museum Library, London

\section{Copyright \& Reuse}

Copyright Status: Public domain. The BHL considers that this work is no longer under copyright protection.

This document was created from content at the Biodiversity Heritage Library, the world's largest open access digital library for biodiversity literature and archives. Visit BHL at https://www.biodiversitylibrary.org. 